\title{
PNP wt Allele
}

National Cancer Institute

\section{Source}

National Cancer Institute. PNP wt Allele. NCI Thesaurus. Code C51016.

Human PNP wild-type allele is located in the vicinity of $14 q 13.1$ and is approximately $8 \mathrm{~kb}$ in length. This allele, which encodes purine nucleoside phosphorylase protein, plays a role in the release of a purine from a purine nucleoside. Certain allelic variants of the PNP gene cause nucleoside phosphorylase deficiency, resulting in severe T-cell immunodeficiency with neurologic disorder in children. 